\title{
The Political role of 'Bihu' in Assam movement (1979)
}

\author{
Debajit Bora \\ Assistant Professor, Centre for North East Studies and Policy Research, Jamia Millia \\ Islamia, debojeetbora@gmail.com, ORCID id: https://orcid.org/oooo-0oo2-6424-2522
}

\begin{abstract}
This paper aims to understand the political role of Assamese traditional performance 'Bihu' during Assam movement in 1979. It argues that beyond its role as Assamese cultural identity, 'Bihu' had transformed itself into a political space and fueled upon expanding the idea of Stage Bihu. While looking at the performance as medium of political messaging, the paper brings together the three specific case studies seemingly unknown in the documented cultural history and located in the rural Assam. The idea is to comprehend the larger scope of traditional performance in accommodating political events. The debates are being weaved together through theoretical frames of historian Eric Hobsbawm's 'Inventing tradition' Thomas Postlewait's 'theatre event' in order to see the transformation and changes within the repertoire of Bihu. The paper tries to resurrect an alternative historical discourse, often neglected by the dominant historical cannons.
\end{abstract}

Keywords: performance, identity, Assam movement, politics, Assam.

\section{Introduction}

Assam movement, 1979 had emerged as one of the strong identity assertion movement in post Independent India mainly revolved around the issue illegal migration from Bangladesh. On June 8, 1979, the All Assam Students Union (AASU) sponsored a 12-hour general strike (bandh) in the state to demand the "detection, disenfranchisement and deportation" of foreigners. That event turned out to be only the first of a protracted series of protest actions. On August 26, 1979, the Asom Gana Sangram Parishad (AGSP) was formed as an ad-hoc coalition to coordinate a sustained state-wide movement. An unprecedented mass popular upsurge followed in the form of sit-ins, picketing in front of government offices, strikes, and symbolic disobedience of the law (Barua, 1986, p. 1192). This was the outcome of 1978 bi-election in Mangaldoi constituency, where large numbers of suspected (immigrant) voters were spotted and immediately erupted into protest-demonstration against the government. The movement lasted till 1985, ended with the historic Assam Accord brought many regional political changes to the state.

Although, this paper is not trying to concentrate to the entire political events of the movement, rather attempts see the reflections through some performances attached to regional performances like Bihu of Assam. Since traditional dance, performance and artistic expressions are often attached to the social identity, hence, when identity conflict occurs in a social system, these expressions become pertinent to the movement as well. Social scientist Arnold Hauser opined this tendency of cultural expression as 'natural bias of art'. He refers to that any artistic expression often incorporates the societal changes within the structure (Hauser, p. 12). If we see 'Assam movement', we would find similar sheds of changes within many cultural performances of

(c) AesthetixMS 2020. This Open Access article is published under a Creative Commons Attribution Non-Commercial 4.o International License (http://creativecommons.org/licenses/by-nc/4.o/), which permits non-commercial re-use, distribution, and reproduction in any medium, provided the original work is properly cited. For citation use the DOI. For commercial re-use, please contact editor@rupkatha.com. 
that time. Digging the historical documents of the time, it is known that the leaders of Assam movement took help of various traditional regional, micro-regional performances to spread their messages. Performance forms such as Bihu, Ojapali, Gayana-Bayana were used as symbolism of 'Assamese nationality' to integrate people and raise the regional questions. Since these cultural performances are intricately connected to the people of Assam as popular mass cultures, hence these helped in consolidating the calls for the movement. Significantly, being popular social performances, structure of performances like Bihu and Ojapali are somewhat flexible in terms to accommodating the larger socio-political change. It brings in concerns of the common uneducated villagers, those who are also the performers of these forms. Without having contemporary notions in their lyrical and performative content, these forms cannot survive as popular mediums. In the case of Assam movement, these performances worked both ways. Firstly, as a community performance, it absorbs political changes within it and secondly, these forms were strategically used by the leaders of the Assam movement. In the larger discussion this paper would aim to understand both sides of the performative mediums, how they respond to a political event.

\section{Bihu performance:}

For Assamese people, the festival of Bihu is more of a cultural identity than just a celebratory occasion. This emotion transformed into a form of resistance during the Assam movement,1979. Local performer and cultural activist like Krishna Kanta Handique remember distributions of Dhols (drum used in Bihu repertoire) by the leaders of the movement to perform Bihu in different places of Upper Assam ${ }^{i}$. Handique recalled that those were not well made Dhols, often made of cheap materials, but distributed to perform in public gathering and protests as a mode of symbol to connect to the Assamese culture. Mainly, those Dhols were being distributed among the people of upper Assam, where this is performed the most. ${ }^{\text {ii }}$ This narrative of Handique proves the point that the leaders of Assam movement were strategically used these folk performances to mobilize the people.

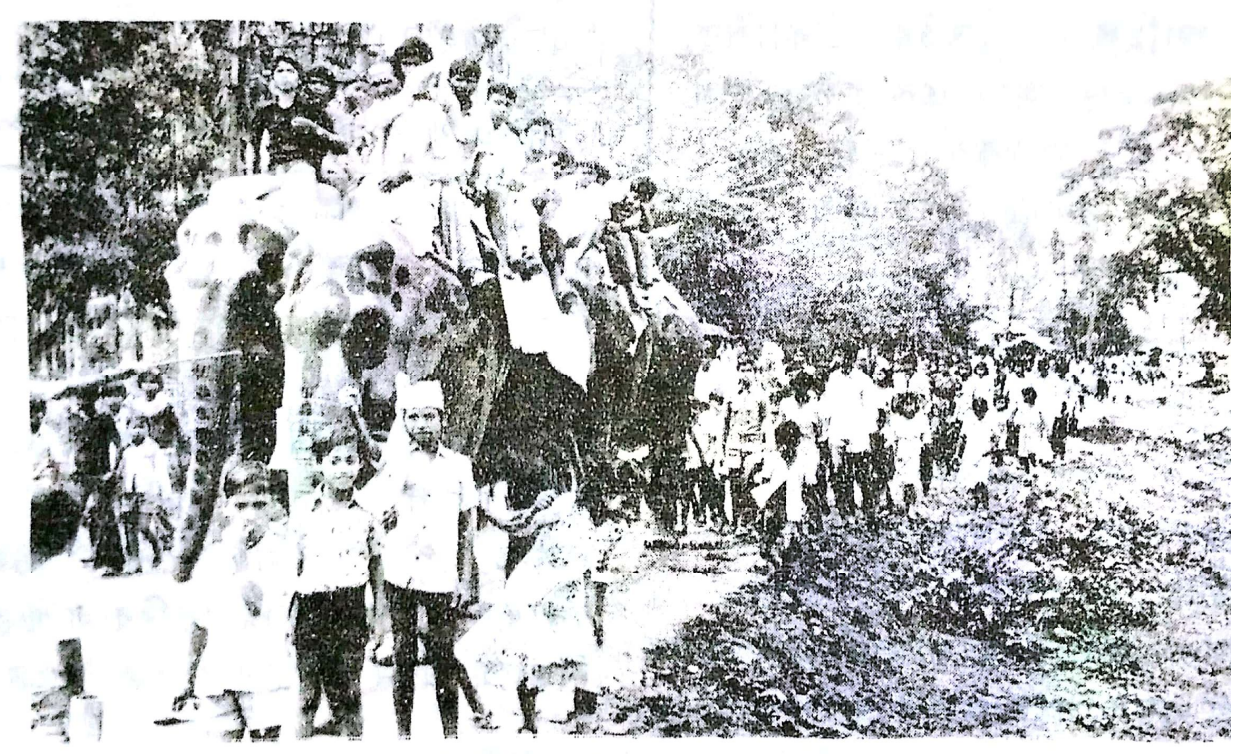

Figure 1. A Bihu procession during Assam movement, 1980 (location unknown). Source: Prantik, September, 1980 
3 | The Political role of 'Bihu' in Assam movement (1979)

A report along with a photograph appeared in premiere Assamese monthly 'Prantik' in 1980, documenting a cultural rally where a group of people were marching in Bihu attires. The photograph taken into an unknown location, published with a powerfully drafted caption symbolized the ethos of the movement. (Figure 1)

The caption says:

"Aiye diya mor bihu gamochare

goli khuwa tej mochi"

\section{English:}

I have used my mother's 'Gamocha' gifted on Bihu

to tie my bullet wound hand.

These are some significant nostalgia of how a political movement like Assam movement engaged with a Bihu festival towards mobilizing the public. While reading it as a dramatic strategy, the performance of Bihu had undergone through a series of transformation and changes to be used in such a fashion. One such is the popularization of 'Stage Bihu' (performance of Bihu in a proscenium stage). From 1980's Bihu became a popular platform for the AASU leaders not only connect to the idea of Assamese/Asomiya culture, but also to mobilize public. As a festival Bihu is perhaps the most connected to each and every community of Assam. Hence, the same became an easily available platform for the movement leaders to get access to the rural as well as urban public.

Very tactfully AASU leaders started investing their interests on Stage Bihu. However, the concept of stage Bihu was popularly enacted in the Latashil area of Guwhati city in 1952. But the real popularity and political transformation took place in 1980's. While initially Stage Bihu was organized to accommodate Bihu dance troupes and dancers in order to celebrate the Assamese New Year ${ }^{\text {iii }}$, but within those politically volatile periods the concept of stage Bihu was used as a platform to not only celebrate Bihu, most importantly invited popular leaders to deliver speeches. News reports of that time are evident of the fact that in many districts, such as Nagaon, Guwahati, Jorhat and Golaghat, Bihu had been a frequent podium for the leaders to visit and communicate with the masses. Leaders such as Prafulla Kumar Mahanta (President AASU), Bhrigu Kumar Phukan (Gen. Secy, AASU), Chandra Mohan Patowary had been seen as speakers. Usually a local committee consisted of local leaders and concerned civil society people used to organize these events, where local Bihu troupes were also invited to perform.

With the transformation in space and content, Bihu as a festival and performance, had undergone many changes in its traditional structure. But above all, the political atmosphere of 1980's helped extensively to canonize Bihu as a 'cultural nationalism'. Therefore, the legacy of Stage Bihu still continues in various part of the state, mainly under All Assam Student Union's (AASU) leadership. This new addition of cultural manifestation can also be seen through the broader framework of 'invented tradition' provided Marxist historian Eric Hobsbawm. While explaining the idea he denotes:

The term 'invented tradition' is used in a broad, but not imprecise sense. It includes both 'traditions' actually invented, constructed and formally instituted and those 
emerging in a less easily traceable manner within brief and dateable period-a matter of a few years perhaps-and establishing themselves with great rapidity. (1983, p. 1).

While connecting 'invented traditions' to the 'nation' and 'nationalism', Hobsbawm analyzes that the National movements often creates new tradition to go with their nationalistic narrative structure (1983, p. 7). This way, what we see in Bihu and Assam movement is just a lucid reflection of Hobsbawm. This new layer of nationalism has brought an overall cultural change and changes like 'Stage Bihu' can be seen as inventing tradition.

\section{Changes in the performance:}

Apart from the structural changes, as a performance the Bihu repertoire, too accepted many changes in its lyrical content. Mainly slogans of the movement were replaced the traditional lyrics. In Golaghat district, Meghai Das, a traditional Dhuliya (drummer) performer vividly captures the memory of his performance during 1980's Bihu; where he and his team used to incorporate many songs from popular slogans of the movement like this:

Aji asomire bukute/ kune jui logale

Desh bulile adeshu amak nelage

Ulai ah homoniya/ desh rakhibole jau

Pran di holeu/ Jibon di holeu/ desh rakhibole jau

Heiyah heiyah hein. ${ }^{\text {iv }}$

\section{English:}

Who put the fire at the chest of my mother Assam?

We don't need orders to fight for our motherland

Come one come all my friends

Let's go to save our motherland

We don't mind to leave our life

We just want to keep our motherland alive. ${ }^{\mathrm{v}}$

Meghai, in our short interaction, reavealed that no one had instructed him or his partners to perform or sing these kinds of songs. It was a pure enactment of spontaneous improvisation. Many of those songs were created on the spot, sometime even while performing. Mention may be made here that Meghai Das is an uneducated performer and a daily wage laborer. Although during Bihu season (April-May) he earns his livelihood by playing Dhol with many Bihu groups of nearby villages. The performances he made during Assam movement, was not in front of huge public gathering or in any functions, rather those were performed in Husoris, (which is a traditional courtyard door to door performance in the village) with nearby village Bihu troupes. He remembers that those kinds of songs were being performed as part of Lora Naas (boy's dance). Meghai's nostalgic interview also exposed us to seemingly unknown as well as ignorant piece of narrative deeply rooted into rural Assam. While the Stage Bihu events were spaces of political engagement specially in the urban milieu, then Husori, the traditional form of Bihu somewhere also played the same role, in a more local arena. Most importantly, this was not in the presence of 
5 | The Political role of 'Bihu' in Assam movement (1979)

any leaders and therefore it proves the fact that the movement did reach to the artists like Meghai, who them himself became the agent of change. This also brings the question of 'cultural locus'. The larger stage Bihu events were happening in the urban locus, where the leaders were included into the program and their speeches were setting the tone. Besides, in the rural locations traditional performances were popular and that is why the contents of the songs had absorbed with the changes. But these local rural cultural narratives were not got into the popular documentation of the movement. Besides, leaders addressing the crowed on stage Bihu became popular in media. I think, traditional performances often keep documenting things within its repertoire. Performances like Bihu is example, which is still keeping the political memories in the form of songs. I identify this as a power of traditional folk performance, which kept absorbing those socio-political memories in its structure. Just because they are traditionally conditioned to a particular locus, they accept the changes and absorb the memories of the changes.

Assam movement is not only a movement against illegal infiltration in the state. It also questions the state's systematic extortion of land, resource and water. As Hiren Gohain explains that the anxiety of bothering Assam is deep rooted in its colonial past (Gohain, 2019). The Oil refinery movement of $1956-57$ is also connected intricately to the regional questions. Few Bihu songs created in areas like Sibsagar and Jorhat had not only incorporated all those issues, but also raised question on central government's role in it. A song still popular among the Bihu performers can be cited to see the reflection:

Kaziranga Kohora/ Numoligarh Bihora

Amar gutei Asom khon/ Telere oi awora

Dangor Dangor sunga loi/ Bidesholoi gusi jay

Amar asom khonok oi/ khali kori thoiye jay ${ }^{\mathrm{vi}}$

\section{English:}

Kohora is in Kaziranga/ Bihora is in Numaligarh

Our beloved Assam is surrounded by oilfields

It exports oil to the foreign countries / in massive tankers

But our motherland became empty and empty. ${ }^{\text {vii }}$

This song often seen in Husori performance, especially while boys' dances (Lora Naas). The lyrics are rhythmically structured, raising questions on exporting large amount of crude oil outside Assam, without any consent of the local people. The lyricist and composer of these songs are unknown, but the popularity of these songs remain the same even today. I think just because these issues are still not resolved and the regional political circumstances are still centering around these issues, hence songs like the one mention above, are still not losing its popularity in the public spaces. This helps us to comprehend the peculiarity of traditional folk performances as a social medium. The 'invented tradition' factor suggested by Hobsbawm, can be seen in a more instrumental shape.

\section{Dhuliya Oja performance:}


The word Dhuliya Oja in Assamese means an expert drummer. This is somewhat different from the traditional Bihu répertoires. Generally, an Oja accompanies by a Taliya (cymbal player), who helps him/her to create drumming rhythms perfectly. The drum beats in Oja performance are faster than the conventional Husori beats and many times the performance is extensively improvised. The structure of this performance was free from any religious binaries unlike many other performances of ancient time. Within the flexible structure, it can easily accommodate entire socio-political happenings in its repertoire. Besides, performances like Dhuliya Oja is meaningless without reflecting upon the contemporary society in its aesthetics realm. This performance believed to be evolved from the Ahom royal courts in 13th-14th century. During Ahom's rule in Upper Assam, this was performed in many ceremonial occasions like marriage, and later it was used extensively for making royal announcement and publicity. Significantly, the performers were mostly belonging to the lower castes. They used to be laborer or a hard worker, but used to perform as Oja out of passion. Today, this performance is increasingly marginalized but once a major part of Assamese culture and a popular performance.

Usually, the performance starts with a Saraswati Vandana (Prayer to goddess Saraswathi) and then go on performing Dhol beats. Oja often use two Dhols, one on his shoulder and the other one in his front and then he plays both in a very typical manner. Within the drumbeats the performer also sings different songs describing the origin of the universe, Assamese society, Dhol and Bihu. It varies perform to performer and location to location. An Oja also converses with the audience, especially when performer try to enact something on contemporary society and politics. Evoking humor is the typical nature of this performance, the comical enactment often through songs and bodily gestures. As I mentioned, most of these performers were from lower castes, often faced discrimination from the upper castes once. Thus, this performance is a significant medium that represents the voices of the oppressed. Often sustainability of this performances are lies within traditional marriage ceremony, although as a pure form of art this is being severely neglected both in discussion and cultural policy implantation. It is extremely important for us to realize the fact that performances don't only amuse people. Every popular performance connected to community or society, equally become a 'site' and 'source' of many historical traces. Which helps us to comprehend a socio-political atmosphere of a time. Scholar John Butt proposes the idea of 'Historically informed performance', where he argues that a performance often related directly to the concept of history. (p. 6) Besides Thomas Postlewait proposes the concept of 'performance event', which absorbs a political event within its aesthetics. (p. 9) Both these arguments echo when we try to understand a very local performance like Dhuliya Oja. Because it helps us to develop an alternative historical discourse away from the canonized notions of history.

To resurrect the sketches of historical scorches during Assam movement, I would like to take you to Horupai Oja and Mahendra Chutiya of Jorhat district, those who recollect memories of the blood hit 1980's. Mahendra Chutiya, a popular Dhuliya Oja, mostly known widely for his appearances in national and regional televisions with the Dhol. He is a professional Dhuliya Oja, who still earns his livelihood only by performing Dhol at different marriage ceremonies and cultural events. Of late, he improvised the art form with newer aesthetics to popularize the same among the youth.

Remembering the days of 1980, he said that he had been invited many Bihu stages to demonstrate his skills. These functions were organized mostly by AASU in collaboration with the local people. Chutiya composed few songs on his own and performed at that time. In our brief meeting he said: 
7 | The Political role of 'Bihu' in Assam movement (1979)

Often Dhuliya Oja's duty is to entertain people. To produce a pure set of entertainment, we engage with the contemporary socio-political happenings. Since this performance is folk performance, hence as artists we had the liberty to perform the way we wanted. ${ }^{\text {vii }}$

During interview, he took his drum in typical manner and started singing few songs from his memories accompanied by spontaneous rhythm of the Dhol. The song goes like this:

Huniyoko Sarbajana

Amaro Bachana

Haat ekhon bojai jau

Huna Sarbajana

Huniyoko Sarbajana...

Aai matri/ aai matri

Dhoru Choronot

Tumar bine goti nai

Ei Jonomot oi / Ei Jonomot

Huniyoko Sarbajana...

Sariufale jolise jui

Tumak bosabole

Bideshi ahi sutal palehi

Khedibole ulai ah oi

khedibole ulai ah

Huniyoko Sarbajana...

Ingrajok khedilu ami/ Poita bhat khai

Mahatmak patilu ami/ Jatire Pitai

Etiya akou ahise bideshi/ himar hiparor porai

Ekeloge khedibo lagibo/ ne ki kowo kokai

Huniyoko Sarbajana... ${ }^{\text {ix }}$

In English: 
Listen to me all of you present here

I just want to perform a series of Dhol beats.

My dear mother

I want touch your feet

Without your blessing

we are nothing

Fires are all around

To save you my mother

Foreigners have reached to the courtyard

Please come out all together

We had forced British to move out

With the strength we gathered having water and rice

We made Mahatma as national father

Now foreigners are coming again from outside of the border

We must force them to go

What do you say my bother?

The song includes various part of Dhuliya Oja repertoire. The first four lines is Arombhoni, meaning an introduction. Here the performer introduces himself to the audience and request audience for an attention. The second segment in called Saraswati Bandana (prayer to goddess Sarawati) there on, Dhuliya takes it away on his own style. Like every ancient folk performance this also intricately connected with social life of the region. Dhuliya Oja performance in a marriage ceremony treats as blessing for the bride and groom. Hence, when the same became a part of social practice as Dhuliya Oja, it took these advantages to convey social messages. Although Chutiya performed these on public meetings and cultural functions during Assam movement, but as a medium it played its part very well arouse the regionalism sentiment.

The other performer Horupai Oja, is approaching his 8o's now. With a weak bodily gesture, he welcomed us at his resident at Alengi, Jorhat. But soon transformed himself to an energetic youth when he holds the dhulor mari in his hand. Oja narrated:

During the movement, he was not involved in performing to a larger crowed but as a traditional performer he used to perform in village weddings. ${ }^{\mathrm{x}}$

The political movement touched his performances too. My second meeting was with him in a bed ridden condition sometime in October, 2017. At that time, he couldn't remember the 
9 | The Political role of 'Bihu' in Assam movement (1979)

lyrics exactly but he recalled that he performed few movement related songs as part of his Bandana segment in few places. He recalled one thus:

Bande Maa-taram

Aji moi ulaiye ahilu

Maa jononir babe

Desh bosabole, Oi Ram

Desh Bosabole

Aji moi ulaiye ahilu...

Raijhokol ahise ulai

Hokoluti ahise ulai

Jorhat te miting ekhon patise

Satra Hantha r lorai

Bande Maa-Taram... ${ }^{\mathrm{xi}}$

\section{In English:}

Long live my mother land...

Today I am coming outside

For the cause of my motherland

I want to save my state/ O dear god

I want to save my state

All the people coming outside

There is meeting

Organise by student leaders

Long live my motherland... ${ }^{\text {ii }}$

Horupai Oja remembered that he performed this song at some local weddings around his locality during 1980's. He himself composed this song incorporating the traditional structure and performed after Saraswati Bandana part. According to him:

The rhythm and structure of this song is also like a Bandana (prayer) but this bandana is directed towards the state of Assam as this responded to the contemporary political situation of that time. ${ }^{\text {xii }}$

The meeting with Harupai Oja and Mahendra Chutiya exposed me to another set of narrative, which didn't go through structural changes like stage Bihu, but responded to the movement in a more subtle and seamless way. This brings many questions around the idea of 'change' and 'natural bias' specially in the context of traditional community performances. As I have suggested 
earlier that the urban locus played an important role in changing the structure from traditional Bihu to a stage Bihu. These urban spaces were primarily for the speeches and secondarily used for the performances. Besides the traditional rural spaces (like marriage ceremony) were the actual spaces, where these performances were mean to be practiced. Hence it did not change the structure but absorbed the 'natural bias' in the lyrics in response to the political atmosphere. Besides, this performance was performed only in the local areas. This didn't part of a cultural processions or a public gathering primarily focused on political activities. These are the reasons perhaps Dhulia Oja performance didn't go through major structural changes like stage Bihu.

\section{Conclusion:}

To understand Bihu's larger role as 'political' I would like see this through the concept of 'theatre event'. Theatre historian Thomas Postlewait proposes the idea of 'Theatre event' which emphasizes on looking at a theatre-performance in contrast to the contemporary socio-political condition. Postlewait beliefs that a theatre performance is not just a theatre performance, but if that connects the larger political or social crisis becomes an 'event' itself. Postlewait says:

...theatre also takes its meaning from the social milieu, including the political conditions, influences, and control that operate at any historical moment." (2002, p.9)

Postelweit broadening the understanding of theatre, which allows to connect with more "political topics, themes, issues, viewpoints and agendas that get expressed in plays, production, theatre groups, and artistic movement (p. 9).

Often when I see performances like Bihu through the paradigm of 'theatre event', it reflects the larger political role of a performance form. Today; Bihu is an identity of Assam/Assamese/Asomiya and Assam sub-nationalism. In many ways, this identity had been reconstructed during Assam movement. The transition of Bihu performance from traditional space to a proscenium stage and subsequent appropriation of the festival to a political space, all factors fostered into the formation of Assamese sub-nationalism. It is also because the political memory that it absorbed within a performance repertoire and content. Today looking back these songs and performances are more like exploring an historical document. Exploring these songs can help us to understand the identity transition of the regions like Assam. Although performances like Bihu demands more exploration and systematic research to bring into academic attention.

\section{Acknowledgement}

The author would like to thank Prof. Bishnupriya Dutt, School of Arts and Aesthetics, JNU, Media Archive, Rupnagar Guwahati, Interviewees and Rupkatha Journal on Interdisciplinary Studies in Humanities, towards helping in pursuing this idea forward.

\section{Endnotes}

\footnotetext{
${ }^{\mathrm{i}}$ Upper Assam refers to the Ahom ruled Assam in the pre-colonial period, started from present day Koliabor to the Tinsukia district of Assam.
} 
ii Krishna Kanta Handique, a local cultural practitioner revealed these informations in a public talk at Sur Samalaya Resource centre for Arts, Sivsagar, Assam in 2017

iii The month of Bohag falls in the mid-April of each year regarded as Assamese New Year and Rongali Bihu is celebrated as a festival during this time.

${ }^{\text {iv }}$ Meghai Das sung these lyrics in conversation with the researcher at his home at Rajanakhat, Golaghat in 2016

${ }^{\mathrm{v}}$ The lyrics has been translated by the researcher from Assamese to English.

${ }^{v i}$ This song is still popular in many regions of the state and I heard it as a practitioner of the same.

${ }^{\text {vii }}$ The song has been translated by the researcher from Assamese to English.

viii This statement was made by Mahendra Chutiya in an interview with the researcher at Jorhat in 2018.

ix This song was sung by Mahendra Chutiya during his interview with the researcher.

${ }^{\mathrm{x}}$ Horupai Oja, a traditional Dhuliya Oja performer lives in Along area of Jorhat district. He spoke to the researcher in 2017 .

${ }^{x i}$ This song was sung by Harupai Oja during his interview with the researcher in 2017.

xii The song translated from Assamese to English by the researcher

xiii Horupai Oja made this statement during his interview with the researcher in 2017.

\section{References:}

Barua, S. (1986). Immigration, Ethnic conflict, and Political Turmoil --Assam,1979-1985. Asian Survey, 11841206.

Butt, J. (2002). Playing with History: The Historical Approach to Musical Performance. Cambridge: Cambridge University press.

Hauser, A. (1990). The social history of art. London: Taylor and Francis.

Hiren Gohain, D. B. (2001). Asom Andolon: Pratisrti aru Falasruti. Guwahati: Banalata.

Gohain, H. (26. feb 2019). Ignoring Assam's Colonial Past While Discussing NRC Is Academic Escapism. Von The Wire: https://thewire.in/rights/debate-ignoring-assams-colonial-past-while-discussing-nrc-isacademic-escapism abgerufen

Hobsbawm, E. (1983). Introduction: Inventing Traditions. In T. R. (Ed.) Eric Hobsbawm, The Inevntion of Tradition (pp. 1-14). London: Cambridge University Press.

Postelwait, T. (2009). The Cambridge Introduction to Theatre Historiography. Cambridge: Cambridge University Press.

Debajit Bora teaches Cultural Studies at the Centre for North East Studies and Policy Research, Jamia Millia Islamia, New Delhi. He is also undergoing his doctoral research at School of Arts and Aesthetics, JNU. He is an M.Phil from JNU and having a Masters in Communication Studies. His research interests includes Politics of performance, Cultural identity and conflicts, Media studies, Cultural mapping and documentation. He is also associated with Research and Documentation Cell of Sur Samalaya Resource Centre for Arts, a primiere cultural organisation in Assam working towards mutliple sphere of culture since 1997. 